\title{
(D)escribir la China en la experiencia misionera de la segunda mitad del siglo XVI: el laboratorio ibérico*
}

\author{
Antonella Romano \\ Centre Alexandre Koyré, EHESS, París \\ antonella.romano@ehess.fr
}

Fecha de recepción: 10/08/2014

Fecha de aceptación: 20/09/2014

\begin{abstract}
RESUMEN
El objetivo de este artículo es el de proponer una reflexión acerca de la especificidad de la escritura misionera como proceso de producción de saber. Sin dar como adquirido el "carácter proto-etnográfico de la escritura misionera", en contra de la lectura tradicional que se nos ofrece desde Claude LeviStrauss, trata de poner en perspectiva las condiciones geopolíticas y aquellos elementos susceptibles de conformar una episteme propia, por medio de los cuales, en la segunda mitad del siglo XVI, la China se convirtió en objeto de saber para el mundo letrado europeo, inscrito en un nuevo marco global. Para ello, se sirve de la lectura conjunta de tres textos que -es la hipótesis del artículo- constituyen la base de una operación historiográfica de esta naturaleza: el Tratado das Cousas da China de Gaspar da Cruz, la Historia de las cosas las mas notables, ritos y costumbres del gran reyno de la China de González de Mendoza, el De Christiana Expeditione apud China de Nicolas Trigault.
\end{abstract}

Palabras clave: China, órdenes religiosas, jesuitas, Gaspar da Cruz, Juan González de Mendoza, Nicolas Trigault, Matteo Ricci, historia de los saberes, primera globalización, escritura, misión

\section{Describing China in the missionary experience during the second half of the sixteenth century: the Iberian laboratory}

\begin{abstract}
The main goal of this article is to develop a reflection about the specificity of missionary writing as a means for the production of knowledge. Rather than endorsing the 'proto-ethnological character of missionary writing' (in the footsteps of Claude Lévi-Strauss), it aims at confronting the geopolitical context with the potential elements of a particular episteme allowing, during the second half of the sixteenth century, for China to be turned into a new topic for the European learned milieu, encompassing thus knowledge production into a new global framework. The article's main suggestion is that the
\end{abstract}

${ }^{*}$ Este trabajo se inscribe en el proyecto MINECO HAR2011-27177. Mi mayor gratitud a Fernando Bouza por su estímulo constante a que tome los senderos abiertos por el mundo ibérico en su descubrimiento del mundo de la época moderna, así como por la traducción del texto que no ha podido sino mejorar tanto en la forma como en el fondo. A Federico Palomo que me ha empujado a escribir estas páginas a modo de esbozo y de reflexión, interlocutor intelectual siempre sugestivo y generoso, mi agradecimiento. 
historiographical operation that encapsulates this process can be located in the cross-reading of three books: Gaspar da Cruz's Tratado das Cousas da China, González de Mendoza's Historia de las cosas las mas notables, ritos y costumbres del gran reyno de la China, and Nicolas Trigault's De Christiana Expeditione apud China.

Key words: China, religious orders, Jesuits, Gaspar da Cruz, Juan González de Mendoza, Nicolas Trigault, Matteo Ricci, history of knowledge, first globalization, writing, mission

"En sorte que par l'industrie Espagnole tout le monde est aujourd'huy cogneu: dont une grande partie estoit demouree incogneuë si long temps: \& communiquent ensemble les extremitez d'Orient, Occident, Septentrion, Midy, s'entrevisitans les hommes separez par tant de mers, si distans \& differens les uns des autres moyennant le navigage rendu plus seur \& plus facile principalement par cette invention [de la brújula]" ["De suerte que por industria española todo el mundo es hoy conocido; del que una gran parte se había mantenido desconocida durante tanto tiempo; y se comunican los extremos de Oriente, Occidente, Septentrión, Mediodía, entrando en contacto los hombres separados por tantos mares, tan distantes y diferentes los unos de los otros mediando la navegación que se ha vuelto más segura y más fácil ante todo por esta invención [de la brújula]".

Louis Le Roy: De la vicissitude ou variété des choses en l'univers, et concurrence des armes et des lettres par les premieres et plus illustres nations du monde, depuis le temps où a commencé la civilité, \& mémoire humaine iusques à présent. Plus s'il est vray ne se dire rien qui n'ayt esté dict paravant: \& qu'il convient par propres inventions augmenter la doctrine des Anciens, sans s'arrester seulement aux versions, expositions, corrections, \& abregez de leurs escrits, París, 1575, fol. $100 \mathrm{v}$.

1. Hoy ya no es preciso tener que demostrar la aportación de las órdenes religiosas a la conformación intelectual de la alta Edad Moderna, en especial en el mundo ibérico y, más en general, en los espacios del catolicismo tridentino. Gracias a algunos importantes trabajos de la investigación española, portuguesa o italiana, profundamente renovadas, transnacionales en sus objetivos y en ocasiones dotadas de una perspectiva comparada, la pesada herencia de la leyenda negra se difumina progresivamente y libera a la historiografía de una agenda de investigación inútilmente limitada a la crítica de la cultura erudita de los medios religiosos, en especial de los seculares ${ }^{1}$.

1 Entre los trabajos colectivos más importantes (no pudiendo dar cuenta aquí del conjunto de monografías que sustentan esta renovación), se deberá distinguir sin duda entre "estilos nacionales" diferentes; destacaremos los que se han centrado en uno y otro imperios, en particular en el ámbito portugués: BETHENCOURT, F. y CURTO, D. Ramada: Portuguese Oceanic Expansion, 1400-1800, Cambridge, CUP, 2007; Marcocci, G.: L'invenzione di un impero. Politica e cultura nel mondo portoghese (1450-1600), Roma, Carrocci, 2011; pero también los que, en España y en la estela de Fernando Bouza, han irradiado la investigación sobre la cultura de lo escrito y del libro en la Edad Moderna: ver en particular Bouza F. (coord.): Cultura epistolar en la alta Edad Moderna, monográfico de Cuadernos de Historia Moderna Anejos IV (2005); ID.: Papeles y opinión. Politicas de publicación en el Siglo de Oro, Madrid, CSIC, 2008; González Sánchez, C. A.: Atlantes de papel. Adoctrinamiento, creación y tipografía en la Monarquía Hispánica de los siglos XVI y XVII, [Rubí, Barcelona], Ed. Rubeo, 2008; Maillard Álvarez, N. (ed): Books in the Catholic World during the Early Modern Period, Leiden, Brill, 2013. En la producción italiana, que ha comenzado más tarde a explorar las 
A este respecto, es bien sabido que la renovación de la que la Compañía de Jesús se ha beneficiado en las dos últimas décadas ha permitido dar impulso a fructíferas investigaciones en especial en torno a la orden ignaciana y la cultura escrita, en una perspectiva que se ha ido alejando no sólo de la historiografía interna que mantuvo protegidas a las órdenes durante tanto tiempo, sino también, de forma más amplia, de la historiografía religiosa aislada y particularizada en el cuadro más amplio de la de la Edad Moderna ${ }^{2}$. Incluso la historia de las ciencias es hoy tributaria de esta aportación, como atestiguan las más recientes investigaciones sobre los imperios ibéricos, en este campo ${ }^{3}$.

Un paso más se ha podido dar integrando las órdenes religiosas en el mapa actual de redes, flujos y lugares de saberes que configuran la Edad Moderna, al haber empezado a enraizarse en la historiografía internacional el paradigma historiográfico de los saberes misioneros ${ }^{4}$. Si aún no es del todo seguro que la expresión llegue a alcanzar una dimensión epistemológica, sí se puede, no obstante, esbozar la hipótesis de que el gesto misionero de la transcripción del mundo por medio de la escritura registra tanto un conjunto de saberes como los protocolos de saber que, con el tiempo, han conducido a los historiadores de las ciencias a considerar las fuentes misioneras como primeros escritos etnológicos. Esto es, al menos, lo que Claude Lévi-Strauss no sólo sugería hace ahora tres cuartos de siglo en las páginas justamente famosas de un escrito de género indefinido, Tristes tropiques, cuando asociaba las narraciones de los viajes

vías de análisis que ofrece la confrontación con la historia global, los trabajos sobre el papado y sobre la diplomacia de la Edad Moderna son, sin duda, los más innovadores: Visceglia, M. A. (dir.): Papato e politica internazionale nella prima età moderna, Roma, Viella, 2013; Giannini. M. C. (dir.): Papacy, Religious Orders, and International Politics in the XVIth and XVIIth centuries, Roma, Viella, 2013.

2 A partir del impulso dado en Francia, desde la década de 1990, por las siguientes publicaciones, Giard, L. (dir.): Les jésuites à la Renaissance. Système éducatif et production de savoir, París, PUF 1995; FABRE, P.-A. y Romano A. (dirs.): Les jésuites dans le monde moderne. Nouvelles approches historiographiques, número monográfico de Revue de Synthèse, 120 (1999), 2-3; FABre, P.-A. y Vincent, B. (dirs.): Missions religieuses modernes. "Notre lieu est le monde", Rome, École française de Rome (Collection de l'École française de Rome, 376), 2007; en Estados Unidos, por los dos volúmenes colectivos, O’Malley, J. W. y otros (eds.): The Jesuits. Culture, sciences, and the arts, 1540-1773, 2 vols., Toronto, University of Toronto Press, 1999-2006. Las investigaciones individuales o colectivas que se ocupan de la cuestión de la contribución intelectual de los jesuitas no han dejado de crecer. Cabe citar a Castelnau-l'Estoile, C. DE, Copete, M.-L., Maldavsky, A., Županov I. G. (dirs.): Missions d'évangélisation et circulation des savoirs. XVI ${ }^{-}-X V I I I^{e}$ siècle, Madrid, Casa de Velázquez (Collection de la Casa de Velázquez, 120), 2011; WILDE, G. (ed.): Saberes de la conversión. Jesuitas indigenas, e imperios coloniales en la frontera de la cristiandad, Buenos Aires, Editorial Sb, 2012. Sobre la dimensión imperial, Coello, A., Burrieza, J. y Moreno, D. (eds.): Jesuitas e imperios de Ultramar, siglos XVI-XX, Madrid, Silex, 2012.

3 Siguiendo a Cañizares-Esguerra, J.: Nature, empire, and nation. Explorations of the history of science in the Iberian world, Stanford, Stanford UP, 2006, Bleichmar, D., De Vos, P., Huffine, K., Sheehan, K. (eds.): Science in the Spanish and Portuguese Empires, 1500-1800, Stanford, Stanford UP, 2009. Del lado portugués, se remite a SARAIVA, L. (ed.): History of Mathematical Sciences: Portugal and East Asia, vol. II, Scientific Practices and the Portuguese Expansion in Asia (1498-1759), Singapore, World Scientific, 2004; ID. (ed.): History of Mathematical Sciences: Portugal and East Asia, vol. IV, Europe and China. Science and Arts in the 17th and 18th Centuries, Singapore, World Scientific, 2013; Saraiva, L. y Jami, C. (eds.): History of Mathematical Sciences: Portugal and East Asia, vol. III, The Jesuits, the Padroado and East Asian science (1552-1773), Singapur, World Scientific, 2008.

4 Véase Romano, A. (dir.): Sciences et mission: le cas jésuite, monográfico de Archives Internationales d'Histoire des Sciences, 148 (2002); ConsI, E. (coord.): Ordenes religiosas entre América y Asia. Ideas para una historia misionera de los espacios coloniales, México, Colmex, 2008. 
de descubrimiento del Nuevo Mundo a los breviarios ${ }^{5}$, sino también veinte años más tarde en un texto breve, pero sin duda de calado aún mayor, en el que la etnología era definida como el tercer estadío del humanismo ${ }^{6}$. Invirtiendo la perspectiva abierta por el antropólogo, es posible preguntarse por la escriturización de la experiencia misionera como un modo de constitución de conocimiento, una fábrica de saberes sobre el mundo moderno pensado en la diversidad de sus expresiones a la que daba pie la diversidad de lo lejano. Esta escritura, que ha terminado por ser para nosotros un reservorio inagotable y, además, a menudo único de saberes sobre el pasado de las culturas sin escrituras, es fruto en primer lugar de un trabajo de aprendizaje, como lo expresan con fuerza las palabras de Francisco Javier:

[...] en ninguna cosa aprovecharéis tanto en las almas a los hombres de esa ciudad [Ormuz], como sabiéndoles sus vidas muy menudamente; y éste es el principal estudio que ayuda a aprovechar a las almas. Esto es leer por libros que enseñan cosas que en libros muertos escritos no hallaréis, ni os ayudará tanto para fructificar en las almas, cuanto os ayuda saber bien estas cosas [...] Y si queréis hacer mucho fruto, así a vos, como a los prójimos, y vivir consolado, conversad a los pecadores, haciendo que se descubran a vos. Estos son los libros vivos por los que habéis de estudiar, así para predicar, como para vuestra consolación. No digo que alguna vez no leáis por libros

5 "Rio est mordu par sa baie jusqu'au cœur; on débarque en plein centre, comme si l'autre moitié, nouvelle Ys, avait été déjà dévorée par les flots. Et en un sens c'est vrai puisque la première cité, simple fort, se rouvait sur cet îlot roicheux que le navire frôlait tout-à-1'heure et qui porte toujours le nom du fondateur: Villegaignon. Je foule l'Avenida Rio-Branco où s'élevaient jadis les villages tupinamba, mais j'ai dans ma poche Jean de Léry, bréviaire de l'anthropologue", Lévi-Strauss, C.: Tristes tropiques, París, Plon, 1955, p. 87. ["Río de Janeiro es mordida por su bahía hasta el corazón; se desembarca en pleno centro, como si la otra mitad, nueva Ys, ya hubiera sido devorada por las olas. Y en cierto sentido es verdad, ya que la primera ciudad -un fuertese encontraba en ese islote rocoso recién bordeado por el barco y que lleva aún el nombre de su fundador: Villegaignon. Camino por la avenida Rio Branco, donde antaño se levantaban las aldeas tupinamba, pero en mi bolsillo tengo a Jean de Léry, breviario del etnólogo", Tristes trópicos, traducción de Noelia Bastard, Paidós, Barcelona, 1988, p. 83]. Es sabido que el texto de Léry al que se refiere Lévi-Strauss no es un relato de misionero, pero la Histoire d'un voyage fait en terre de Brésil es una narración de una conquista espiritual del Brasil por parte de los protestantes franceses llegados para colonizar esta tierra de América del Sur.

6 ID.: "Les trois humanismes", en Anthropologie structurale, París, Plon, 1973, vol. II, pp. 319-322 (primera edición en Demain, $\mathrm{n}^{\circ} 35,1956$ ): “A la plupart d'entre nous, l'ethnologie apparaît comme une science nouvelle, un raffinement et une curiosité de l'homme moderne [...] Pourtant, il y a là une illusion dangeureuse, dans la mesure où elle trompe sur la place réelle qu'occupe, dans notre vision du monde, la connaissance des peuples lointains. L'ethnologie n'est ni une science à part, ni une science neuve: c'est la forme la plus ancienne et la plus générale de ce que nous désignons du nom d'humanisme. Quand les hommes de la fin du MoyenAge et de la Renaissance ont redécouvert l'antiquité gréco-romaine, et quand les Jésuites ont fait du grec et du latin la base de la formation intellectuelle, n'était-ce pas une première forme d'ethnologie?" ["A la mayoría de nosotros, la etnología se nos presenta como una ciencia nueva, un refinamiento y una curiosidad del hombre moderno (...) Con todo, hay ahí una ilusión peligrosa, en la medida en que engaña a propósito del puesto real que ocupa, en nuestra visión del mundo, el conocimiento de los pueblos lejanos. La etnología no es ni una ciencia aparte ni una ciencia nueva: es la forma más antigua y más general de lo que designamos con el nombre del humanismo. Cuando los hombres de la Edad Media, y del Renacimiento, redescubrieron la Antigüedad grecorromana, y cuando los jesuitas hicieron del griego y el latín el fundamento de la formación intelectual, ¿no se trataba de una primera forma de etnología?", "Los tres humanismos", Antropología estructural. Mito, sociedad, humanidades, México, Siglo XXI, 1979, p. 257]. 
escritos, mas sea biscando autoridades para autorizar por la Escritura los remedios contra los vicios y pecados que leéis por libros vivos $[\ldots]^{7}$.

Y aquí se abre paso una primera constatación: la que se desprende del hecho de que el misionero pone en tensión dos formas opuestas de aprendizaje, entre lo vivo y lo muerto, entre lo que es intermediado por hombres y lo que es transmitido por libros escritos. La metáfora del saber muerto de la escritura es una provocación, que expresa la posición de un misionero que se encuentra entre el pasado, apostado en los libros, y el futuro, que le abre el cara a cara con lo desconocido ${ }^{8}$. Al hacerlo así, le asigna un objetivo: aprender a conocer a los hombres desconocidos. Le impone, como consecuencia, una misión: extraer de este conocimiento un saber que sea transmisible. Si no es seguro que la instrucción dirigida por Francisco Javier en 1549 a Gaspar Berze (Barzeus), que se preparaba para dejar Goa por Ormuz, "développe une stratégie missionnaire qui passe par le savoir, une véritable approche scientifique de la conversion, appelée ici 'le progrès des âmes"", se puede en cambio buscar, en

7 "Carta a Gaspar Barzeus", Cartas y escritos de S. Francisco Javier, edición de Félix Zubillaga, Madrid, BAC, 1953, p. 326-327. "Rien ne sera plus profitable pour le salut des âmes des habitants de cette ville [Ormuz] si ce n'est que vous connaissiez leur vie tout à fait par le détail. C'est la principale étude que vous avez à faire, car elle aide beaucoup au progrès des âmes. C'est cela que savoir lire dans des livres qui enseignent des choses que vous ne trouverez pas dans les livres morts écrits et rien ne vous aidera autant à faire du fruit dans les âmes que d'apprendre à bien connaître ces choses... Et si vous voulez produire beaucoup de fruit, aussi bien en vous-même que chez vos prochains, et vivre consolé, conversez avec les pécheurs de façon à ce qu'ils se confient à vous. Eux, ils sont les livres vivants que vous devez étudier aussi bien pour prêcher que pour être consolé. Je ne vous dis pas de ne pas lire parfois les livres écrits, mais que ce soit pour y chercher des citations d'Autorités, des remèdes à apporter aux vices et aux péchés que vous lisez dans les livres vivants", citado en Castelnau-L'Estoile, C. y otros: "Introduction" a Castelnau-L'Estoile, Copete, Maldavsky, Županov, op. cit. (nota 2), p. 1.

8 En el marco de una orden religiosa cuya identidad por entonces se había construido también alrededor de su vinculación con los estudios y la inversión intelectual. La Compañía como orden intelectual se ha convertido en un lugar común historiográfico. Cultivado por la propia Compañía, ha contribuido sin duda a sobrevalorar esta componente, no sólo en el seno de la orden, sino como parte también de su identidad. Esta dimensión intelectual se ha visto alimentada de modo particular por el antijesuitismo que se fue conformando con el desarrollo mismo de la orden. Véase, sobre esto, FABre, P.-A. y MAIre, C: Les antijésuites. Discours, figures et lieux de l'antijésuitisme à l'époque moderne, Rennes, PUR, 2010. Sobre la imagen de la orden, Oy-Marra, E., Remmert V. (dirs): 'Le monde est une peinture'. Jesuitische Identität und die Rolle der Bilder, Berlin, Akademie Verlag, 2011.

9 [“... desarrolla una estrategia misionera que pasa por el saber, un verdadero acercamiento científico de la conversión, llamada aquí "el progreso de las almas"']. Castelnau-L'Estoile y otros, op. cit. (nota 7), p. 1. Cito también la continuación: "Le monde est perçu comme une bibliothèque dans laquelle existent des livres 'morts' (les livres déjà écrits) et des livres 'vivants' qui sont à inventer, à déchiffrer et à mettre par écrit. C'est aussi parce qu'ils traitent de la vie des hommes et des femmes en société, que ces livres sont vivants. Le missionnaire, formé dans les 'livres morts' et observateur des 'livres vivants', a pour tâche d'enrichir la bibliothèque du monde. Alors que la mission en Inde ne fait que débuter, François Xavier perçoit d'emblée l'entreprise missionnaire comme une démarche intellectuelle. Au même moment, en Nouvelle-Espagne, le franciscain Bernardino de Sahagún est en train de décrire le monde aztèque à l'aide d'informateurs indigènes, dans un livre resté pendant des siècles à l'état de manuscrit, caché au fond d'une bibliothèque. La relation entre missions et savoirs, pensée chez François Xavier comme dialectique et complémentaire, est faite aussi de tensions, de rapports de concurrence, d'interdits et de renoncements". ["El mundo es percibido como una biblioteca en la cual existen libros 'muertos' (los libros ya escritos) y libros 'vivos' que restan por ser descubiertos, descifrados y trasladados a la escritura. También porque se ocupan de la vida de los hombres y de las mujeres en sociedad, estos libros son vivos. El misionero, formado en los 'libros muertos' y observador de los 'libros vivos', tiene como objetivo hacer más rica la biblioteca del mundo. Cuando la misión en India no 
el análisis de la narración misionera, la expresión del paso desde la experiencia y la observación a la producción de un saber. Cabe, así, considerar la hipótesis de que la constitución de la nueva ciencia experimental, desde finales del siglo XVI, también encontró en el laboratorio de la misión un espacio para su elaboración. Es de ello de lo que querría ocuparme, mostrando cómo, en el período considerado, ese laboratorio misionero construyó un nuevo objeto de saber: China.

2. Para la Europa del siglo XVI, la entrada en un sistema-mundo, calificado hoy de "primera globalización”, coloca a China en una situación paradójica: la de ser un horizonte conocido, pero un espacio y una historia desconocidos, como se señala, por ejemplo, en la primera parte del libro de Etiemble, L'Europe chinoise ${ }^{10}$. Éste nos recuerda hasta qué punto China era, para el mundo letrado del siglo XVI, una referencia cuyos lazos con los núcleos europeos de la cultura son reconocibles desde que éstos se dotaron de historia ${ }^{11}$. Pero continúa siendo un espacio desconocido, que la reactivación del comercio mundial alrededor del globo, estimulada por el "descubrimiento" del Nuevo Mundo, hizo que los europeos integrasen en sus zonas de intercambio. A las tradicionales rutas terrestres de Eurasia, forjadas a lo largo de toda la Antigüedad y de la Edad Media, se añaden a partir del siglo XV las rutas marítimas de los dos océanos Pacífico y Atlántico, que generan geopolíticas imperiales distintas, pero en cuyo seno las monarquías ibéricas desempeñan un papel determinante. De la misma forma que revelaron la existencia de un nuevo continente que hasta entonces había escapado al conocimiento del mundo, las vías marítimas trazadas por los navíos portugueses y españoles confirman la inmensidad que se había sospechado, la riqueza entrevista, la complejidad y la familiaridad supuestas ${ }^{12}$ de un Catay de contornos

había más que empezado, Francisco Javier se da cuenta de que la empresa misionera es un esfuerzo intelectual. Por entonces, en Nueva España, el franciscano Bernardino de Sahagún está a punto de describir el mundo azteca con la ayuda de informadores indígenas, en un libro que durante siglos ha permanecido manuscrito, oculto en el fondo de una biblioteca. La relación entre misiones y saberes, pensada por Francisco Javier como dialéctica y complementaria, está también hecha de tensiones, de relaciones de competencia, de prohiciones y de renuncias"].

10 Etiemble, R.: L'Europe chinoise, 2 vols., París, Gallimard, 1988-1989.

11 Se puede encontrar un conjunto de fuentes sobre este intercambio, ibidem, vol. 1: De l'Empire romain à Leibniz, primera parte: "A la recherche de Cathay", p. 45-57. Aunque de manera más significativa para nuestros propósitos, la cultura erudita del Renacimiento ya había formulado esta idea. Así se desprende a la perfección de la lectura del texto del helenista francés Le Roy, L.: De la vicissitude ou variété des choses en l'univers, et concurrence des armes et des lettres par les premieres et plus illustres nations du monde, depuis le temps où a commencé la civilité, \& mémoire humaine iusques à présent. Plus s'il est vray ne se dire rien qui n'ayt esté dict paravant: \& qu'il convient par propres inventions augmenter la doctrine des Anciens, sans s'arrester seulement aux versions, expositions, corrections, \& abregez de leurs escrits, Paris, Chez Pierre 1'Huilier, 1575. A ello se refieren un buen número de textos italianos, portugueses a través del desarrollo de dos géneros muy distintos, las historias de estados y los relatos de viaje. Una investigación más sistemática y a gran escala debería permitir que un día se completase esta cartografía todavía harto limitada.

12 Etiemble, op. cit. (nota 10), vol. 1, “Avant-propos. Le chef-d'œuvre de l'imposture européocentriste: Gutemberg serait l'inventeur de l'imprimerie”, dedicado a denunciar la impostura historiográfica del siglo XX sobre los orígenes europeos de la imprenta, contra el estado de los conocimientos en la Edad Media, marcado por el (re)conocimiento de los orígenes chinos de la imprenta. Por contra, Etiemble nos recuerda que los textos del XVI no dejan lugar a dudas. Junto a Le Roy, Montaigne, M. DE: Essais, París, Chez Abel L'Angelier, 1588, t. III, 9, p. 397: "Nous nous escriïons, du miracle de l'inuentiõ de nostre artillerie, de nostre impression: 
territoriales aún imprecisos, pero de hecho cerrado, como lo estará en las décadas siguientes Japón, a la presencia extranjera:

Et quand ores toutes les seigneuries Chrestiennes et Sarrasines seroient reduittes soubs une obeissance, ne pourroient estre comparées a la sienne. Il commande à plus de sept cens lieues de pays bien habité \& peuplé plein de beaux edifices à nostre mode, villages, bourges, chasteaux, villes riches \& fortes, affluence de vivres, \& de toutes sortes d'artisans exquis. Les Cathains ou Chinois ont telle opinion d'eux mesmes qu'ils pensent estre les premiers du monde, estimans les autres hommes borgnes, \& veoir clairement des deux yeux à cause de leur subtilité et \& habileté, faisans ouvrages tant propres que ne semblent estre faicts de main d'homme, ains par la nature mesme ${ }^{13}$.

De esta síntesis, destacaremos dos elementos: la participación del mundo ibérico en la constitución de China como horizonte de saber para la Europa del siglo XVI; el carácter excepcional del papel jugado por los misioneros en el establecimiento, pasajero o permanente, de europeos en China. Mientras que en otros contextos geopolíticos su presencia se añade a la de comerciantes, diplomáticos, militares o viajeros, en el corazón de China ellos son los únicos, no extranjeros, pero sí venidos del Oeste. Cuando esta presencia, frágil y limitada, se hace constante, es sostenida ante todo por las monarquías ibéricas, no sólo el Portugal del Estado da Índia, sino también la España de los conquistadores. Los primeros llegaron por Oriente y se instalaron a las puertas del Imperio Medio a partir de su fondeadero desde 1563, Macao; los segundos se acercaron por Occidente, desde Sevilla por la Nueva España, más tarde desde las Filipinas recientemente conquistadas, puerta del mar de la China y de las costas y riquezas de $\mathrm{Asia}^{14}$. Si los mercaderes tomaban parte en las relaciones con objetivos

d'autres hõmes, vn autre bout du monde à la Chine, en iouyssoit mille ans auparauant" ["Consideramos como milagrosa la invención de la artillería y la de nuestra imprenta, y otros hombres en el otro extremo del mundo, en la China, gozaban de ellas mil años ha”, en Ensayos, traducción de Constantino Román y Salamero, París, Garnier, 1912]

13 Le Roy, op. cit. (nota 11), fol. 92v. ["Y cuando todas las señorías cristianas y sarracenas fueran reducidas a una única obediencia, no podrán ser comparadas con la suya. Manda a más de setecientas leguas de un país muy habitado y poblado lleno de bellos edificios a nuestro modo, pueblos, burgos, castillos, ciudades ricas y fuertes, abundancia de víveres y de toda suerte de artesanos exquisitos. Los catayos o chinos tienen tal opinión de sí mismos que piensan que son los primeros del mundo, estimando que los otros hombre son ciegos y que ellos ven claramente de ambos ojos a causa de su sutileza y su habilidad, haciendo obras tan propias que no parecen hechas por mano de hombre, sino por la naturaleza misma"].

14 Sobre la presencia portuguesa en China, Loureiro, R. M.: Fidalgos, Missionarios, e Mandarins. Portugal e a China no seculo XVI, Lisboa, Fundação Oriente, 2000; ID.: Na companhia dos livros: Manuscritos e impressos nas missões jesuitas da Ásia Oriental, 1540-1620, Macao, Universidade de Macau, 2007; para España, Ollé, M.: La empresa de China. De la Armada invencible al Galeón de Manila, Barcelona, Acantilado, 2002. Las primeras señales del interés español por China están documentadas, en el archivo de Sevilla, por las cartas del misionero Martín de Rada, quien ofrece una de sus primeras descripciones al virrey de Nueva España: “Andado tiene el Reyno en la China quinze provincias treze que llaman ponchin y la de paquiaa y la de Canquiaa. La de Paquiaa es la corte donde reside el Rey y la de Canquiaa es la de su hermano. Las demas son governadas por visorreyes [pag. 2] que llaman Ponchinsi y cada uno dellos reside en la ciudad mas principal de su provincia y pone otros ocho tenientes en ocho ciudades de su virreynado y cada uno destos tenientes pone diez governadores en diez pueblos sujetos a su ciudad los quales tambien son pueblos grandes y tienen sujetas muchas aldeas que cada una dellas terna de jurisdiccion diez o doze leguas. Dizen ser tierra pobladisima y tan avasallados que pasando por alguna calle qualquier governador todos los dela calle aun mucho antes que llegue se arriman a las paredes y le hazen gran humiliaçion y nadie le habla sino es de rodillas 
comerciales que se desarrollaban a través de las ciudades portuarias del litoral -y los puertos chinos estaban más que acostumbrados, los venidos de Europa no eran más que los últimos en la larga duración de la historia de los intercambios económicos de Asia-, los misioneros, llevados por un proyecto de conversión, participaban en las dinámicas de conquista espiritual, que pasaban no sólo por la presencia en las zonas litorales y urbanas, sino también en los territorios del interior. En este sentido, el "descubrimiento" de China corresponde a la Europa católica. De esta forma, cuando los relatos de viaje se multiplicaban, dando cuenta de la vinculación cada vez más clara del continente europeo con el resto del globo y de la diversidad de informaciones que acarreaba esta nueva literatura apodíctica -baste con recordar a Richard Haykluit para la Inglaterra isabelina-, los textos misioneros se distinguen por su impronta confesional, sus objetivos, sus finalidades. Es en función de tales especificidades que deben ser tratados aquí ${ }^{15}$.

3. La escritura misionera hace, por tanto, que surja un nuevo objeto y horizonte de saber para la Europa de la segunda mitad del siglo XVI: China. Es posible circunscribir su geneología a una trilogía, que se despliega en tres tiempos, cuatro órdenes religiosas, cinco escenas y una multitud de actores: en 1569-1570, el impresor español de Évora, André de Burgos, publica por vez primera en Europa

\footnotetext{
y los ojos bajos. Todos han de tener officio. No es nadie governador ni soldado de guarnicion en su tierra sino de otras provincias ponen los mandadores y la gente de guarnicion en cualquiera de las ciudades y solo estos pueden traer armas, los demas ni aun tenerlas en sus casas y asi es la gente mas vil para la guerra que ay en el mundo aunque pelean a cavallo y a pie pero el de cavallo no lleva espuelas y para pelear suelta las riendas y pelea a dos manos. No dura un officio de estos mas de tres años y cada año les enbia el rey un visitador. Esto y otra cosillas se supieron por la relacion de aquel chino que hasta que se vean no se pueden tener por ciertas. Quisimos en un navio dellos embiar alla un par de religiossos porque los mismos chinos se ofrecian a ello pero nunca quiso el governador sino fuese o por mandato del rey o de vuestra excelencia. Dixome que avia embiado a pedir licencia al governador de Chinchiu para embiar alla el año que viene un par de hombres a tratar con el de la paz y contratacion. No se que respuesta daran a vuestra excelencia. Suplico embie a mandar que si pudiera ser se embien alla un par de religiosos por que de mas de que podra ser se abra gran puerta al evangelio y servicio de nuestro señor servira tambien de que ternemos de alla verdadera noticia de lo que ay y ellos declararan a los chinos la grandeza de nuestro rey y quan bien les esta en tener su amistad y si ellos reciben la fe les daran a entender la obligaçion que tienen a servir a su Magestad pues a su costa y provision les embia ministros que les enseñen y aunque no fuese más de servir de lenguas y que se pudiese contratar con ellos, no sería poco importante su ida, y para ello, si a mí me lo mandasen, lo ternía por particular merced, y lo haría de muy buena voluntad.", Copia de una carta quel Padre fray martin de rrada provincial de la orden de San Agustin que reside en la china escribe al virrey de la nueva spaña fecha en la ciudad de manilla a 10 de agosto de 1572, Archivo General de Indias (AGI), Patronato, 24, n 1, R.22. Véase también "Relaçion verdadera de las cosas del Reyno de Taibin por otro nombre china y del vuaje que a el hizo el muy reverendo padre fray Martin de Rada provincial que fue de la orden del glorioso Doctor de la yglesia San Augustin, que lo vio y anduvo en la provincia de Hocquien año de 1575", Bibliothèque Nationale de France, París (BNF), Fonds Espagnol, 325.9 (MF 13184), fols. 15-30.

15 No podemos ocuparnos ahora de los desafíos historiográficos a los que remiten los siguientes puntos aclaratorios: el primero tiene que ver con la participación del mundo ibérico en la producción europea de saberes sobre el mundo, una participación durante mucho tiempo minusvalorada por la historiografía internacional; el segundo, sobre el reconocimiento de la agency misionera en esos mismos procesos; el tercero remite a la adopción de un enfoque ibérico, que da la espalda a los marcos de análisis nacionales que han dominado ampliamente la escritura de la historia de las relaciones entre España y Portugal en la Edad Moderna; el cuarto se refiere a la reevaluación de los intereses asiáticos de la España del XVI y, en especial, de Felipe II.
} 
un texto entera y exclusivamente consagrado a China, el Tratado das Cousas da China, del fraile dominico Gaspar da Cruz (c. 1520-1570) ${ }^{16}$; en 1585, el agustino Juan González de Mendoza (1540-1617) publica en Roma, en español y, un año más tarde, en traducción italiana, la Historia de las cosas las mas notables, ritos y costumbres del gran reyno de la China ${ }^{17}$, obra que incluye la edición de textos manuscritos provenientes de misioneros franciscanos; en 1615, el jesuita Nicolas Trigault (1577-1628), llegado a China desde Douai, en los Países Bajos españoles, y reenviado a Europa en 1610 para representar a sus correligionarios ante Roma, remite a sus superiores el manuscrito de una obra que consiste en una reescritura de las anotaciones de Matteo Ricci (1552-1610). Enviadas por el centro romano de la Compañía al impresor Mangium, en Augsburgo, la publicación apareció en 1615 bajo el título De Christiana Expeditione apud China.

Esta genealogía reúne tres empresas editoriales cuyo principal punto en común consiste en el hecho de que las tres pretenden singularizar un mismo espacio, China, constituyéndolo así en objeto de análisis. En este sentido, la segunda y la tercera tienden a hacer de la primera una fuente, una fuente que conviene citar y descalificar al mismo tiempo, en el marco de una competencia que se sitúa en un doble plano, político y religioso. Dibuja la evolución de los temas que supone el horizonte extremo-asitático para el mundo católico. En este sentido, cada uno de los tres textos corresponde a una agenda que es diferente, pero que dota a la Europa mediterránea, así como a los otros países implicados en la conquista marítima del mundo, de un conjunto de conocimientos cuya precisión irá creciendo, de un libro a otro, a lo largo de toda la época moderna. Esta trilogía revela, no obstante, un gesto más amplio, de matriz igualmente misionera, aunque no exclusivamente: en 1577 , Bernardino de Escalante (1537-1605) hacía imprimir en Sevilla el Discurso sobre la navegación que los portugueses hacen a los reinos y provincias de Oriente, y de la noticia que se tiene de las grandezas del reino de la China ${ }^{18}$; diez años más tarde Giovanni Pietro Maffei (1536-1603) editaba los Historiarum Indicarum libri XVI. Selectarum item ex India epistolarum libri $I V$, que contiene una larga descripción de China ${ }^{19}$; entre tanto, las cartas de los misioneros ocupados en lejanos territorios eran reelaboradas en los centros culturales del catolicismo, Roma, Madrid, Lisboa

\footnotetext{
16 Hacemos referencia aquí a la edición moderna, GASPAR DA CRUZ: Tratado das coisas da China: Évora, 1569-1570, ed. R. M. Loureiro, Lisboa, Cotovia, 1997. Las citas a continuación se tomarán de esta edición. Se remite también a Loureiro, op. cit. (nota 14, 2000), cap. 24, pp. 617-645. Véase, además, LACH, D. F.: Asia in the Making of Europe, Chicago, The Chicago University Press, 1965-1977, vol. 1/2, pp. 565 y ss. En la historiografía francesa es conocido como Gaspar de la Croix. Sobre la incertidumbre en torno a la fecha, véase Loureiro, R. M., "Introdução" a Gaspar da Cruz, op. cit. (nota 16), p. 13, n. 1. J. Spence es, por su parte, aseverativo en cuanto al año 1570: SPence, J.: Chinese Roundabout. Essays in History and Culture, New York, W. W. Norton, 1992, p. 2. Existe de hecho una edición de 1569.

17 González de Mendoza, J.: Dell'historia della China descritta dal p.m. Gio. Gonzalez di Mendozza dell'Ord. di s. Agost. nella lingua spagnuola. Et tradotta nell'italiana dal Magn. M. Francesco Auanzo, cittadino originario di Venezia, Roma, Bartolomeo Grassi, 1586, que sigue la versión española, publicada en Roma en 1585.

18 Escalante, B. DE: Discurso de la navegacion que los portugueses hazen à los reinos y prouincias del Oriente, y de la noticia que se tiene de las grandezas del reino de la China, En Seuilla, en casa de la biuda de Alonso Escriuano, 1577.

19 Florencia, apud Philippum Iunctam, 1588.
} 
y todos los grandes centros urbanos de la imprenta, asegurando así una primera forma de familiaridad, ampliamente difundida y a buen precio, con espacios tan lejanos como China $^{20}$.

El primero de los textos por fecha, dedicado al rey de Portugal D. Sebastián, se presenta como el resultado de un largo periplo del misionero dominico entre India y China en los ventiún años anteriores a su regreso a Évora, período en el que había sido enviado a fundar la primera misión asiática de su orden. Dividido en veintinueve breves capítulos, de orden de dos a tres páginas cada uno, el libro hace gala de un saber fundamentado en el itinerario de Gaspar da Cruz, a lo largo de las costas: en principio las de India, que recorre antes de fundar una casa en Malaca, más tarde cuando se embarca hacia el reino de Camboya, donde se detiene por espacio de un año, remontando en especial el río Mekong. Es entonces cuando desde Camboya decide lanzarse hacia China, donde ya se encuentra a fines del año 1566, en la bahía de Cantón, obteniendo la autorización de las autoridades chinas para pasar de allí a Guangdong, donde se detiene un mes. A comienzos del año de 1557, está de regreso en Malaca, en donde se le pierde la pista hasta volver a encontrarlo en Ormuz, que abandona en 1563, a buen seguro para regresar a India, desde donde vuelve a Portugal en 1569. Estas fechas no pretenden tanto esbozar una biografía del misionero dominico como poner en evidencia un punto que aparece aquí de manera muy clara: el tratado sobre China descansa sobre una experiencia directa de apenas unos meses, sin duda no más de tres, limitada a la zona litoral de Canton-Guangdong, zona cosmopolita por excelencia desde antiguo. Pero de su larga peregrinación asiática, regresa también con fuentes escritas disponibles sobre las rutas de Eurasia que frecuenta; se añaden los testimonios de otros europeos que tuvieron la posibilidad de permanecer tiempo en China y eventualmente tener acceso a fuentes chinas. Por ello, sugiere desde la introducción: "[...] conforme a minha possibilidade, assim do que vi como do que li num compêndio que [fez] um homem fidalgo que cativo andou pela terra dentro, como do que ouvi a pessoas dignas de fé" ${ }^{21}$. Gracias a sus interlocutores, según lo que él mismo escribe, logró hacerse con una copia manuscrita del texto de Galiote Pereira, soldado portugués, cuya experiencia sobre el terreno se basaba en los tres años que había pasado en las prisiones chinas a comienzos de la década ${ }^{22}$. El hecho de que esto sucediese en la provincia de Sichuan hace aún más precioso este

20 No se desarrollará este punto. A simple título de ejemplo, Copia de algunas cartas que los padres $y$ hermanos de la compania de IESUS, que andan en la india, y otras partes orientales, escrivieron a los de la misma Compania de Portugal. Desde el año M.D.LVII hasta el de lxj. Tresladadas de Portugues en Castellano. Impressas en Coimbra por Ioan Barrera. 1562, in- $4^{\circ}$, Lisboa, Biblioteca da Ajuda (BA), 55-III14/1; Cartas dos padres e irmaos da Companhia de Iesus, que andao na India nos Rivas do Japao dos da mesma Companhia em Europa, des do anno de 1549. Coimbra, 1570, in-12 ${ }^{\circ}$, con dedicatoria al obispo de Coímbra, BA, 50-VI-28. Para su estudio sistemático, sigue siendo referencia insustituible la obra de LACH, op. cit. (nota 16), vols. 1 y 2.

21 GaSPar da CruZ, op. cit. (nota 16), p. 66.

22 BoXer, C. R.: South China in the sixteenth century, being the narratives of Galeote Pereira, Fr. Gaspar da Cruz, O.P. [and] Fr. Martín de Rada, O.E.S.A. (1550-1575), Londres, printed for the Hakluyt Society, 1953. 
testimonio secundario, puesto que, a mediados del siglo XVI, Pereira fue uno de los pocos europeos que estuvo en el interior de $\mathrm{China}^{23}$.

En el caso de la obra española, nos encontramos ante una operación mucho más sofisticada de capitalización de experiencia, pues la obra es compuesta, como se indica en el largo título: además de un texto redactado por el mismo González de Mendoza $^{24}$, el volumen se ofrece como una suma de textos elaborados anteriormente, aunque habían permanecido manuscritos, todos ellos sobre China y que procedían de misioneros españoles de las antiguas órdenes mendicantes: los agustinos Martín de Rada $^{25}$ y Jerónimo Marín ${ }^{26}$, de 1577, y los franciscanos Pedro de Alfaro ${ }^{27}$ de 1579 y Martín Ignacio, en el mismo período ${ }^{28}$. Se puede, así, describir la operación editorial a cuya cabeza se coloca González de Mendoza como un acto de capitalización de experiencia y de observación directa, puesta al servicio del imperio español recientemente convertido en ibérico y cuya capital, Madrid, había requerido el envío de informaciones sobre China en la estela de su reciente establecimiento en Filipinas ${ }^{29}$. Capitalización que funciona también como captación, si se la compara con el texto de Gaspar da Cruz y si se considera en medida del eclecticismo narrativo de que se compone: el texto es compuesto, como la monarquía española ${ }^{30}$. La publicación se inscribe también en el rastro de un discurso de la conquista de China, ya de dos decenios de antigüedad ${ }^{31}$ y coetáneo al establecimiento en Manila, las dificultades de la situación económica y política del archipiélago filipino y las esperanzas de riqueza que suscita la proximidad de un gran territorio, que se ha hecho familiar por la presencia masiva de mano de obra china en Manila. Datan de este período las primeras

23 Sobre los orígenes y fechas de G. Pereira es muy poco lo que se sabe: mercenario portugués presente en el Mar de China, participó en el comercio de contrabando, próspero en esta zona y en este período. Fue hecho prisionero por las autoridades chinas en 1549, huyendo de su prisión en fecha desconocida. Véase BoxER, op. cit. (nota 22).

24 Nacido en Torrecilla de Cameros en 1545 y muerto en 1618 en América, agustino; Pérez, L.: “Origen de las misiones franciscanas en el Extremo Oriente", Archivo Ibero-Americano, 2 (1914), pp. 202-228.

25 Véase Boxer, op. cit. (nota 22). No existe por ahora ningún trabajo de relevancia sobre Martín de Rada (1533-1578). Su manuscrito Las cosas que los padres Fr. Martín de Rada, provincial de la Orden de S. Agustín en las Islas Filipinas, su compañero Fr. Jerónimo Marín y otros soldados que fueron con ellos vieron $y$ entendieron en aquel reino no fue publicado durante su vida.

26 Escalante, op. cit. (nota 18).

27 Sobre Pedro de Alfaro no hay trabajos, salvo las cartas redactadas en 1578 [Archivo Histórico Nacional, Madrid (AHN)] en las que se da algunas informaciones sobre China.

28 Martin Ignacio de Loyola: Viaje alrededor del mundo, véase la edición moderna de J. Ignacio Tellechea Idígoras, Madrid, Historia 16 ("Cronicas de America", 54), 1989; véase además FerNÁNDEZ, L.: "Las misiones de Indias y Extremo Oriente vistas por un sobrino de San Ignacio, Fray Martín Ignacio de Loyola, 1584", Hispania sacra, 46 (1994), pp. 519-528; GruzInski, S.: Les quatre parties du monde. Histoire d'une mondialisation, París, Éd. de La Martinière, 2004, pp. 278-285, donde también es evocado M. de Rada, que pertenencería a las "élites católicas mundializadas", junto a otras muchas figuras mencionadas por Gruzinski.

29 Sobre el momento político preciso, OLlé, op. cit. (nota 14).

30 Sobre la monarquía compuesta, Elliotr, J.: "A Europe of Composite Monarchies", Past and Present, 137/1 (1992), pp. 48-71. Sobre el texto propiamente, Romano, A.: "La prima storia della Cina. Juan Gonzales de Mendoza fra l'Impero spagnolo e Roma”, Quaderni storici, 48/1 (2013), pp. 89-116.

31 Pero que, al hacerlo, encuentra eco en el de América, un siglo y medio más tarde, y en el corazón de un debate siempre renovado sobre su legitimidad. De esta forma, a finales del XVI, sobre el frente asiático del imperio español, se replantea la cuestión, no resuelta, abierta por el frente americano. A propósito de la apertura española hacia el Pacífico, véase el catálogo de la reciente exposición de Sevilla, Pacífico: España y la Aventura de la Mar del Sur, Archivo General de Indias, septiembre de 2013 - febrero de 2014. 
indagaciones lanzadas por la monarquía española sobre el océano Pacífico, bajo el control en especial de Juan López de Velasco ${ }^{32}$. El activismo de las órdenes religiosas y del clero secular no puede seguir siendo minusvalorado, como indican los numerosos documentos que se encaminan hacia España, emanados de autoridades civiles o religiosas, que mezclan argumentos económicos, culturales y religiosos, para abogar en favor de la ocupación de China, bien por el medio de la invasión o de la simple presencia $^{33}$.

A treinta años de distancia, la publicación de Trigault señala la derrota política de los objetivos asignados por Mendoza a España y a las órdenes mendicantes, la victoria, desde el punto de vista tanto religioso como cultural, de la toma de posesión de la Compañía de Jesús sobre la China europea, y el triunfo de Roma sobre el espacio ibérico en lo que a la producción de saberes se refiere. Desde 1615 y hasta el corazón de las Luces, la producción misionera sobre China estuvo casi exclusivamente monopolizada por la orden ignaciana y se impone como fuente sobre el Imperio Medio, incluidos también sus oponentes y detractores ${ }^{34}$. Fruto de otro tipo de operación libresca, la Histoire de l'expédition chrétienne au royaume de la Chine se presenta como el primer balance de la actividad de la generación pionera de los jesuitas en China. Fue editada por Nicolas Trigault, a partir de anotaciones de Matteo Ricci ${ }^{35}$. La obra, que coloca a la China jesuita en el paisaje cultural europeo, aspira a imponer la misión erudita como llave del éxito de la evangelización de China. La operación historiográfica, que está en su médula, es también concebida como una operación de comunicación dirigida en primer lugar a los estados católicos, pero que a la postre se impone, más allá de las fronteras confesionales, al conjunto de Europa. Eclipsando así el libro de Mendoza, que siguió no obstante siendo leído y circulando en traducciones en las distintas lenguas vernáculas europeas, la publicación de Trigault consigue presentar una China como conmensurable a Europa.

La obra, que durante mucho tiempo ha sido considerada el manuscrito de Ricci ${ }^{36}$, se compone de cinco libros, divididos en capítulos, de los cuales el primero ofrece un cuadro sintético de China, y los cuatro siguientes describen el progreso de la Compa-

32 En 1574 somete al Consejo de Indias su Geografia y descripción universal de las Indias, inédita hasta 1601. Véase Headley, J. M.: "Spain's Asian Presence, 1565-1590: Structures and Aspirations”, The Hispanic American Historical Review, 75/4 (1995), pp. 623-646, en especial p. 631, n. 25.

33 Véase el comentario de Headley: "Whatever the riches and attractions of China itself, the Chinese were here represented as a people of idolaters, sodomists, robbers, and pirates, peculiarly prone to revolt yet somehow ripe for Christianity" (ibidem, p. 634). Asimismo, Ollé, op. cit. (nota 14), y el conjunto de la documentación disponible en http://www.upf.edu/asia/projectes/che/autors/autors.htm. Agradezco a Fernando Bouza que me haya indicado su existencia.

34 Este monopolio descalificará a España como espacio de producción de saberes sobre China. En cambio, los orígenes portugueses y franceses de numerosos misioneros presentes en China continuaron alimentando, hasta años recientes, esta historiografía. A título de ejemplo, véase LourEIRo, op. cit. (nota 14, 2000 y 2007); Pinot, V.: La Chine et la formation de l'esprit philosophique en France (1640-1740), Paris, Paul Geuthner, 1932.

35 De Christiana Expeditione apud China, Augsburgo, Mangium, 1615. Edición francesa: Lyon, Horace Cardon, 1616.

36 El descubrimiento del texto original de Ricci, por parte del P. Tacchi Venturi, en 1909, dio lugar a la publicación Ricci, M.: Opere storiche, edite a cura del Comitato per le onoranze nazionali, con prolegomeni, e note del P. Pietro Tacchi Venturi, vol. 1: I commentari della Cina; vol. 2: Le lettere dalla Cina, Macerata, Tip. F. Giorgetti, 1911-1913. Constituye una nueva edición Fonti Ricciane, ed. de P. M. D'Elia, vol. 1: Storia dell 'introduzione del cristianesimo in Cina, Roma, La Libreria dello Stato, 1942; vol. 2: Storia dell 'introduzione 
ñía en China desde Francisco Javier a la muerte de Ricci. Por su carácter unificado y coherente, por su objetivo claramente explicitado desde el título y la posibilidad de ir apoyando la narración en una trama narrativa simple y continua, la de los avances de la evangelización de China por los jesuitas, el texto, que se fundamenta en modelos narrativos similares y salidos de la misma matriz jesuita, se convierte en el patrón a partir del cual serán escritas más adelante todas las historias de China, hasta la de Du Halde, que responde a un modelo renovado y conforme al horizonte intelectural erudito de las Luces; tal es, al menos, la hipótesis de lectura que sugiero ${ }^{37}$.

Hay pues, en la constitución de la trilogía Cruz-Mendoza-Trigault, un medio siglo de profundos transformaciones de las relaciones entre el mundo católico y Asia. La producción de estos textos obedece a lógicas diferentes y su misma materialidad así lo atestigua: formato, calidad de la impresión, número de páginas, todo podría apoyar la imposibilidad de comparar estas tres obras. Se puede, en sentido inverso, considerar estas evoluciones morfológicas como resultado mismo del proceso de acumulación de saberes del que suponen, cada una de ellas, un hito inevitable.

4. Resulta determinante en la decisión de haber seleccionado estos tres textos de entre un conjunto más amplio el hecho de que cada uno de ellos se construye sobre la base de un "conocimiento previo" de China, un conocimiento reivindicado, que pretende establecer una legitimidad propia al saber que se decide compartir ${ }^{38}$. En este punto, el horizonte chino, como desde hacía ya más de un siglo el de América, ofrece un nuevo desafío no solamente a la cartografía europea de los saberes sobre el mundo por entonces extendido a sus cuatro continentes, sino también a su gramática. El alargamiento del inventario del mundo, tal y como había sido cuidadosamente forjado por los antiguos, todavía procedía del gesto filológico, pero también de la observación directa. Los libros de los antiguos no lo habían dicho todo; la escritura, profana

del cristianesimo in Cina, seconda parte, Roma, La Libreria dello Stato, 1949; vol. 3: Appendici e indici, Roma, La Libreria dello Stato, 1949.

37 En conjunto, se han dedicado pocos estudios a este texto fundamental: sobre el manuscrito de Ricci y la edición de Trigault, se remite a Foss, T. N.: "Nicholas Trigault, S.J. Amanuensis or Propagandist? The Role of the Editor of Della entrata della Compagnia di Giesù e Christianità nella Cina", en Lo KuANG (ed.): International Symposium on Chinese-Western Cultural Interchange in Commemoration of the 400th Anniversary of the Arrival of Matteo Ricci, S.J. in China (Taipei/Taiwan, Republic of China, september 11-16, 1983), Taipei, 1983, pp. 1-94; FezzI, L.: "Osservazioni sul De christiana expeditione apud Sinas suscepta ab Societate Iesu di Nicolas Trigault", Rivista di storia e letteratura religiosa, 34/3 (1999), pp. 541-566; GERNET, J.: "Della entrata della Compagnia Giesù e Christianità nella Cina de Matteo Ricci (1609) et les remaniements de sa traduction latine (1615)", Comptes rendus de l'Académie des Inscriptions et Belles-Lettres, (janv.-mars 2003), p. 61-84.

38 Por contra, cuando Maffei debe redactar sus páginas sobre China, para la obra antes citada, escribe directamente a Matteo Ricci, en busca de ese conocimiento de primera mano que ofrece el misionero. En esos mismos años de 1580, autores no misioneros solicitan a Ricci a su vez, como muestra la carta de respuesta a Juan Bautista Román, factor de las Islas Filipinas y agente de Felipe II. Hay varias copias de la "carta que le escribió el P. Matheo Resi, italiano de la Compañía de Jesús, que reside con el P. Miguel Ruggiero en la ciudad de Juaquín, cabeza desta provincia de los Cantones en los Reynos de la China, i donde reside el Virrei desta dicha provincia, la qual recebí en Macao, veinte leguas de Cantón, he cincuenta de Juaquín"; por ejemplo en AGI, Filipinas 29; Archivo del Museo Naval, Madrid (AMN), Colección Fernández Navarrete XVIII, fol. 146, dto. 31). Véase Ricci, M.: Lettere (1580-1609), edizione realizzata sotto la direzione di P. Corradini, a cura di F. D’Arelli, Macerata, Quodlibet, 2001, pp. 33-41 y 57-87. 
o sagrada, no había sido toda revelada. Al aumentar todos los saberes del mundo, era necesario darles una nueva lectura: si América obligaba a reflexionar sobre las fronteras de la naturaleza y de la civilización, en especial en el marco del gran debate sobre la naturaleza de los indios ${ }^{39}$, China planteaba otra cuestión, la de la civilización sin Dios. Para un catolicismo en plena crisis -el retroceso territorial frente a los otomanos, la escisión definitiva entre católicos y protestantes- esta cuestión no era secundaria. Y los escritos misioneros no podían dejar de tratarla.

Lo que se desprende, de manera unánime, de la trilogía que aquí nos ocupa es la idea de un universo cultivado y civilizado. La apreciación, fundamentada sobre la experiencia, no es ambigua:

E porque entre estas gentes de que fiz menção, os chinas a todos excedem em multidão de gente, em grandeza de reino, em excelência de policia e governo, e em abundância de possessões e riquezas - nem em coisas preciosas como é ouro e pedras preciosas, senão nas riquezas, disposições e fazendas que principalmente servem a necessidade humana -, e porque estas gentes têm muitas coisas muito dignas de memória, me movi a dar notícia geral de suas coisas ${ }^{40}$.

Estos son los motivos que Gaspar da Cruz da, al inicio de su libro, para explicar su elección de consagrarlo a China y el impresor español que lo edita es suficientemente sensible a ello como para retormarlos en su prefacio ${ }^{41}$. El respeto que sale a relucir en ciertos pasajes se traduce en ocasiones en una verdadera admiración por el país; admiración por su inmensidad y por la capacidad de control de la misma, desde el punto de vista de las riquezas, de la extensión o de la eficacia de la organización política; por la constatación del refinamiento - de los vestidos, de la alimentación, del urbanismo y de la arquitectura- como elementos sobre los que se funda una forma evidente de comparación respetuosa; por el predominio, finalmente, de una cultura letrada. Cruz, de hecho, da cuenta del sistema de exámenes.

Este sistema, cuya descripción tampoco dejó indiferente al helenista francés Le Roy ${ }^{42}$, también es mencionado y cada vez de una forma más ampliamente desarrollada por sus sucesores. Mendoza le dedica un capítulo entero (libro 3, cap, 14) ${ }^{43}$ y

39 De Gerbi, A.: La disputa del Nuovo mondo: storia di una polemica, 1750-1900, Milano-Napoli, Ricciardi, 1955, a PAgDen, A.: The Fall of Natural Man: The American Indians and the Origins of Comparative Anthropology, Cambridge, Cambridge UP, 1983.

40 Gaspar da CRUZ, op. cit. (nota 14), p. 66.

41 Ibidem, p. 57: "E porque eu sei Vossa Alteza exceder a todos nisto, e que deseja ver coisas novas, em especial as da China, de que há tanto que dezir que põem admiraçam aos ouvintes".

42 Le Roy, op. cit. (nota 11), fol. 92v: "Ils ont les lettres et disciplines en singuliere recommandation, estime \& honneur, ne recevans à souveraine dignité, \& autres charges publiques, sinon les doctes. Attendu qu'en la distribution des magistrats ils ne regardent à la noblesse ou richesse: ainsi seulement au sçavoir \& à la vertu". ["Tienen en especial consideración, estima y honor a letras y disciplinas, no recibiendo a dignidad soberana y otros cargos públicos más a que los doctos. En atención a que en la distribución de magistrados no miran a la nobleza o riqueza: sino tan solo al saber y a la virtud']. Se puede considerar a Cruz como la principal, sino la única, fuente del helenista francés.

43 MendozA, op. cit. (nota 17), p. 96-100: "Questo è come fargli gentil'huomini, \& habilitargli à qual si voglia giudicatura, \& governo: Et perche il modo, \& la cerimonia, che s'usa nel fargli, è degna d'essere intesa, ho voluto porla in questo luoco, come l'ho trovata nelle relationi del sopranominato Padre Herrada, e de i suoi compagni, che la videro à fare nell città d'Auchieo" (p. 96). 
ocupa un número aún más importante de páginas en Trigault ${ }^{44}$. La descripción es más minuciosa y completa y testimonia un conocimiento preciso debido a una práctica prolongada de observación de dicho sistema y de evaluación de su funcionamiento. Si esta atención particular puede en parte explicarse por la sensibilidad de los autores por todo lo relativo a las letras, también es reveladora de la importancia y de la visibilidad de los mandarines en el mundo chino. Evoca asimismo al hecho de que, cuando los misioneros pusieron pie en el territorio, la existencia de una burocracia letrada permitió el desarrollo de formas de intermediación entre Europa y China, como atestigua el largo camino de Matteo Ricci en el espacio físico, social y político controlado por los Ming ${ }^{45}$.

Además del sistema de exámenes, la cultura china, su antigüedad, sus bases escritas provocan la admiración de los misioneros. Los ideogramas no son cuestionados como escritura, contrariamente a lo que sucede con los códices americanos. A propósito de los caracteres chinos, Cruz constata:

Não têm os chinas letras certas no escrever, porque tudo o que escrevem é por figuras ${ }^{46}, y$ fazem letras por parte, pelo que têm muito grande multidão de letras, significando dada uma coisa por uma letra [...] Esta é causa porque em toda a China ha muitas linguas $[\ldots]^{47}$.

Mendoza les consagra un capítulo entero del tercer libro de su propio texto, remitiendo además a los ejemplares de libros chinos que se encuentran en la Biblioteca Vaticana y en la de El Escorial ${ }^{48}$. Indica, además, en su narración que Martín de Rada, del que edita un texto, había regresado de China, en los años de 1570, con libros, un centenar según él; compra suspendida tras la prohibición hecha por el rey de China de que salieran desde entonces del reino ${ }^{49}$. De la lista que establece, la primera obra mencionada es una "descripción de todo el Reyno de la China y a qué parte está cada una de las quinze Prouinzias (...) y los reynos con quien confinan" ${ }^{50}$. Es difícil comprender la naturaleza de esta obra, pudiéndose suponer que si se tratase de material cartográfico, Mendoza lo habría precisado. Los otros libros adquiridos por Rada dan

\footnotetext{
44 En la parte primera del libro, capítulo 5, totalmente dedicado a artes y ciencias. Edición original latina, 1615 , pp. 42 y ss.

45 Sobre el sistema de exámenes, Elman, B: Civil Examinations and Meritocracy in Late Imperial China, Harvard University Press, 2013. Sobre los letrados intermediarios, Jami, C., Engelfriet, P. y Blue, G. (eds.): Statecraft and Intellectual Renewal in Late Ming China: The Cross Cultural Synthesis of Xu Guangqi (1562-1633), Leiden, Brill, 2001. Sobre M. Ricci, dentro de una abundante literatura, BERnARD-MAÎTRE, H.: Le père Mathieu Ricci et la société chinoise de son temps (1552-1610), Tientsin, Hautes Études, 1937; HsIA, R. Po-Chia: A Jesuit in the Forbidden City. Matteo Ricci, 1552-1610, New York, Oxford UP, 2010.

46 B. de Escalante escribe: "No tienen los Chinas numero de letras en abecedario, porque todo lo que escriven, es por figuras...", EscAlanTE, op. cit. (nota 18), p. 62.

47 Gaspar da CRUZ, op. cit. (nota 14), pp. 187-188.

48 MendozA, op. cit. (nota 17), p. 93: "non sarà fuor di proposito parlar hora de i caratteri, del modo di scrivere, $\&$ anco de gli studii loro. Venendo adunque al primo, dico, che se ben son pochi quelli, che non sappiano leggere, \& scriver fra loro, non hanno pero alcun alfabeto di lettere, come habbiamo noi, ma scrivono ogni cosa con figure, che s'imparano con lunghezza di tempo \& con gran difficoltà, havendo quasi ogni parola un particolar carattere". La mención de los libros chinos se encuentra en la página siguiente.

49 Véase infra.

50 Mendoza, op. cit. (nota 17), p. 104.
} 
informaciones sobre la organización del Estado, con sus riquezas (imposición, administración), sus sujetos, su flota, antes de ocuparse de la historia de China. Después las creencias y ceremonias, previamente a las leyes y la justicia. Los conocimientos médicos son repertoriados enseguida, después los conocimientos astronómicos y astrológicos, su arte de la música y del ajedrez, matemáticas, aritmética, antes de una larga lista de textos sobre astrología natural y judiciaria, quiromancia, fisiognómica, la escritura, la ciencia de los caballos, la interpretación de los sueños, el ceremonial de corte. Esta lista, casi borgiana, se ha construido sobre la doble polaridad de la relación con China: de una parte, el reconocimiento de su potencia y organización; de otra parte, el conflicto frente a un sistema de lectura del mundo fundado en la superstición.

Muchas de las observaciones precedentes valdrían para el texto jesuita, más detallado, pero, ante todo, con una relación distinta con la lengua de los letrados. El salto dado es considerable: no se trata solamente de testimoniar la extrañeza de un sistema de escritura que no estaría fundando sobre el alfabeto, sino de aprovecharlo:

Le P. Matthieu commença le premier cette estude des lettres Chinoises, qui en après estant d'avantage affleuré de ce qu'il avoit appris, se rendit admirable aux lettres chinoises, qui n'avaient jamais leu aucun estranger, duquel ils peussent apprendre quelque chose. Nous parlerons donc expressement de cela en ce chapitre, afin que la posterité sçache combien on a estimé que ceste seule chose a esté proufitable, \& que les Européens qui liront ceci, entendent que leur soin n'a pas esté mal emploié parmi si grand nombre de beaux esprits qui liront ceci. Le P. Matthieu commença donc, comme a esté dict ci-dessus, par les preceptes Cosmographiques et Astrologiques, \& encore qu'il ne leur ait rien apporté de nouveau ou rare, que communément les Lettrés d'Europe ne sachent, neantmaoins parmi eux, qui defendoient opiniatrement les erreurs intolerables qu'ils avoient receus de leurs Ancestres, cela fut trouvé plus admirable, qu'on ne sçaurait croire. Par quoi, plusieurs que l'ignorance de chose meilleure, avoit iusqu'à present rendus obstinez \& superbes, confessoient maintenant qu'on ley avoit ouvert les yeux, pour voir des choses tres-serieuses, qui jusqu'alors avoient estée fermees d'un aveuglement intolerable, ce qui les avoit empesché de comprendre tant de merveilles. ${ }^{51}$

En el espacio de cincuenta años desde el punto de vista del registro de la información por parte de Europa, en realidad en las dos décadas que separan la experiencia de Gaspar da Cruz, en los años de 1560, y la de Matteo Ricci, desde los de 1580, la

51 Ibidem, p. 819-820. ["El primero de todos que començó este estudio de las letras Chinas fue el Padre Mateo, que se confirmó después en lo que avía aprendido con admiración de los letrados, los cuales hasta entonces no avían leído a estrangero de quien pudiessen aprender algo. Trataré de propósito en este capítulo aquesta materia, para que los sucessores no ignoren cuánto es el socorro i la aiuda que en ella sola está colocada, i para que los Europeos que lo leieron no piensen que se an empleado mal sus estudios en esta fertilidad de ingenios. Començó pues el Padre Mateo como arriba se a dicho por los preceptos de la Cosmografía i de la Astrología, i aunque no les llevó cosa alguna mui rara i que no la sepan los ordinarios Letrados de la Europa, empero entre los Chinos, los cuales defendían unos intolerables errores, que avían aprendido de sus antepassados, parecía cosa, más de lo que se puede creer, admirable. Assí muchos a quien la ignorancia de lo mejor avía hasta entonces hecho pertinazes y sobervios confessavan hidalgamente que se le avían abierto los ojos en cosas gravíssimas que por tenerlos cerrados hasta aquel día no las sabían”, Istoria de la China y cristiana empresa hecha en ella por la Compañía de Jesús, traducción de Duarte Fernández, Sevilla, Ramos Bejarano, 1621, 242r.-v.] 
relación con la lengua ha constituido la línea de demarcación entre órdenes mendicantes y jesuitas. La inversión en su aprendizaje, a un coste cuya importancia no puede ser minusvalorada, es lo que ha permitido producir un nuevo tipo de saber y de legitimación del mismo.

El acceso a la lengua, en un principio un obstáculo para Cruz, después mediado por chinos bilingües para Rada, pero también de numerosos jesuitas, es no obstante concebido como una posibilidad por Ricci, y esto es lo que traslada Trigault. Sin volver aquí sobre las fases del establecimiento y del paso de los jesuitas en China ${ }^{52}$, se recordará brevemente que después de instalarse los portugueses en Macao, la Compañía abrió allí una casa en 1563. Tras la primera visita de Alessandro Valignano (1539-1606), en 1578-79, se fundó el colegio de San Pablo y es enviado un hombre, elegido por sus talentos intelectuales, el italiano Michele Ruggieri (1543-1607) ${ }^{53}$. Se le asignó expresamente el encargo de aprender la lengua china. En 1582 se le unió Matteo Ricci. Que los misioneros estaban divididos sobre la posibilidad y la pertinencia de un aprendizaje como éste es lo que se desprende de las cartas que uno y otro envían a sus correligionarios. Pero son empujados por el provincial Valignano, que es el maestro de obra de esta política de la lengua: mientras no hubiera un núcleo de hombres que pudiesen dominar el mandarín, era imposible e inútil intentar lanzarse a la conversión de este país ${ }^{54}$. En el mismo momento, un observador externo, agente de la monarquía española, Juan Bautista Román, confirma, en una carta a Felipe II, no sólo la importancia estratégica de esta inversión, sino también su resultado para la administración china: haciendo del aprendizaje de la lengua de los letrados el instrumento del diálogo entre europeos y chinos, los jesuitas han ganado la confianza de sus interlocutores ${ }^{55}$.

52 La referencia sigue siendo Bernard-Maître, H.: L'apport scientifique du Père Matthieu Ricci à la Chine, Sienshien o Tientsin, Mission de Sienshien, 1935. Véase, más recientemente, AraúJo, H. PeIXoto DE: Os Jesuitas no Imperio da China: o primeiro século (1582-1680), Macao, Instituto Português do Oriente, 2000. Sobre Macao, Hsia, op.cit. (nota 45), cap. 3, p. 51-77.

53 Véase Bernard-MAître, op. cit. (nota 52), p. 56 y ss. Merece la pena destacar la evocación novelesca hecha por Bernard-Maître de los meses pasados por Valignano en Macao: "Tout le temps qui n'était pas pris par les affaires, le Père Valignano le donnait à compulser les livres chinois dont sa chambre était pleine, avec l'aide des interprètes déjà réunis" [Todo el tiempo que no estaba ocupado por los asuntos, el Padre Valignano lo dedicaba a compulsar los libros chinos de los que estaba llena su habitación, con la ayuda de intérpretes que había reunido].

54 Fonti Ricciane, op. cit. (nota 36), vol. 1, p. LXXXIX, sobre las directivas remitidas por Valignano a los de Macao en 1582: "circa quattro Fratelli i quali si mettano di proposito a imparare la lingua mandarina, a scrivere e a leggere [il cinese], studiando pure i costumi e tutto quello che è necessario per poter tentar questa impresa quando piacerà a Nostro Signore; essi non debbono distrarsi in altre occupazioni, nè il Superiore della casa deve distrarli occupandoli in altre cose; difatti finchè non abbiamo alcuni dei Nostri che sappiano la lingua mandarina è impossibile poter tentare con frutto questa tanto desiderata conversione della Cina".

55 Véase supra, nota 38. "Dos cartas desde Macao del Factor Real de Filipinas Juan Bautista Román a Felipe II" (Macao, 25-6-1584 y 27-6-1584), AGI, Patronato 25, 22: "Con la dilaçión de la partida de esta nave por no haver hecho tiempo, aunque pueda salir del puerto, se me ha ofreçido que [...] avisar a vuestra magestad del modo que se podría tener en llevar el presente y cartas al rrey de la China, de manera que le llegue a sus manos y sea enterado de la real voluntad de vuestra magestad si vuestra magestad es servido de ello, y digo que según la grandeza y rriqueza de este príncipe havía de ser de cosas esquisita y costosas, que valiesen en essos rreinos hasta sesenta o setenta mill ducados, conforme a la memoria que en otra carta embío. Ésto se havía de llevar a las yslas Philipinas, donde se podría abrir y orear y rreformar los cavallos, de allí puede el governador despachar dos navíos con alguna gente luzida y buena artillería, y su aparato de 
Ricci se dispone a hacerlo y comparte, con Ruggieri, las mismas dificultades, las de desarrollar un método, con sus profesores de lenguas. Una descripción fragmentaria de este método es ofrecida por Ruggieri: "Fu necessario che con pinture me insegnasse le lettere cine e ancho la lingua; come, per exemplo, volendomi insegnar come se chiama il cavallo in quella lingua e come se scrive, pintava un cavallo e sopra di quello pintava la figura che significa cavallo, e si chiama $m a^{\text {"56. Importa }}$ aquí menos tratar de establecer el grado de conocimiento de la lengua china por los primeros misioneros que insistir sobre estos dos puntos: la decisión tomada, a escala de la orden, de hacer que algunos la aprendieran; la dificultad de su dominio, incluso para los mejores. Aparece, en efecto, desde las primeras cartas escritas desde allá. Se trata al mismo tiempo de explicar el funcionamiento y de indicar cómo proceder en el aprendizaje. A los del colegio de Padua, desde su llegada, Ricci les da algunas claves de comprensión, en especial sobre la dimensión caligráfica de la escritura:

Subito mi detti alla lingua cina et prometto a V. R. che è altra cosa che né la greca, né la todesca; quanto al parlare è tanto equivoca che tiene molte parole che significano più di mille cose, et alle volte non vi è altra differentia tra l'una e l'altra che pronunciarsi con voce più alta o più bassa in quattro differentie de toni; e così quando parlano alle volte tra loro per potersi intendere scrivono quello che vogliono dire; ché nella lettera sono differenti l'una dell'altra. Quanto alla lettera non è cosa per potersi credere se non da chi lo vede o lo prova come ho fatto io. Ha tante lettere quante sono le parole o le cose, di modo che passano di settanta mila, e tutte molto differenti e imbrugliate [...] il loro scrivere più tosto è pingere; e così scrivono con pennello come i nostri pintori.

chirimías y pinturas de las armas rreales y otras cossas tales, y yr derechos a la çiudad y rrío de Canton, y entrar haziendo salvas muy cumplidamente y de aquí se ha de conducir a Paquín, donde el rrey rresside por medio de los virreyes de las provinçias que están delante, comenzando desde el de Xauquin, y es çierto que s una vez este virrey lo despacha, no osarán los otros hazer otra cosa, demás que será pública y de gran rrumor por todos los reynos y ninguno se atreverá a interrompello, para lo que más espero llevar provisión de este virrey que manada de la corte con que se pueda venir seguramente, y aunque se no se [...] por agora, no hay dubda sino que, llegando allá con este ruido y llevando los padres de la Compañía de Jesús, el presente sería admitido por el conoçimiento que tienen ya de ellos, allende de que los padres Miguel Rrugero y Matteo Ricci, vuestra magestad, saben ya escrivir, leer y hablar la lengua china rrazonablemente, y entonces la sabrán mejor y podrán declarar las cartas de vuestra magestad al Rey y a los del consejo, y darles a entender todo lo que se pretendiere, pues no ay oy otros intérpretes en el mundo que sean de provecho, y ha deparado Dios estos dos padres que lo serán tan fielmente, y personas que con la mucha prudencia y habilidad significarán a los chinas todo lo que conviniere para dexar fraguada esta correspondencia y amistad, y servirán a vuestra magestad con mucho amor en ello y en todo lo que les mandare de su profesión, demás de que ay otros muchos de esta orden que son conoçidos de los chinas de treinta años a esta parte, y los tienen por hombres synceros y verdaderos y se fiarán de ellos y no de otros rreligiosos que no conoçen hasta agora, antes a los padres de San Françisco que han aportado a su tierra, algunas veces los an tenido siempre presos en las cárceles por hombres sospechosos y no ha servido su venida sin para darles qué imaginar y [...] Quise avisar a vuestra magestad no por particular devoçión ni afiçión que yo tenga a los de la Compañía, sino porque teniendo la cosa presente, veo lo que conviene en este caso a el serviçio de Dios y de su magestad, y assí affirmo por verdad (a mi pareçer) infalible que conforme a la disposiçión en que agora queda este negoçio y todos los de esta tierra, no se podrá conseguir la amistad de los chinas ni llevar el presente y cartas de vuestra magestad al rrey, ni interpretárselas sin intervençión de los padres de la Compañía, y que con ella se podrá llevar y negoçiar todo lo que se pretende fáçilmente y no de otra manera, como se verá por los effetos, si vuestra Maestad manda ponerlo en execución".

56 Fonti Ricciane, op. cit. (nota 36), vol. 1, p. XCIX. El análisis de D’Elia contrasta con el de Po-Chia Hsia, que, por el contrario, presenta un misionero incompetente en lo lingüístico: HsiA, op. cit (nota 45), p. 108. 
Tiene questa utilità che tutte le nazioni che hanno questa lettera, se intendono per lettere e per libri, benché siano di lingue diversissime, il che non è con la nostra lettera ${ }^{57}$.

Pero, comprende rápidamente la necesidad de deshacerse de intérpretes y desde octubre de 1585 puede escribir que él está sólo y sabe leer y escribir, aunque mal ${ }^{58}$.

Con el campo chino, la experiencia lingüística revela dos asuntos principales del trabajo misionero y de su articulación sobre la actividad intelectual. La complejidad lingüística, unida al hecho de que la lengua china no pertenece a la familia de las lenguas alfabéticas, plantea de inmediato a la cultura europea nuevas cuestiones que la conquista del Nuevo Mundo no había permitido conceptualizar de la misma manera, en especial en función del hecho de que los pictogramas amerindios -algunos de los cuales, raros, habían escapado a la destrucción, se habían convertido en objeto de conservación en los grandes centros de la cultura escrita que representaban las bibliotecas públicas en curso de formación- no se beneficiaban del mismo soporte que en China o en Europa, a saber la imprenta. Pero esta complejidad hace de quienes dominan semejante lengua intermediarios de primera importancia. No sólo son representantes de la figura del intérprete: Ruggieri, Ricci pasan de una lengua a la otra -y muy rápidamente pasaran de textos europeos al chino, sino también de textos chinos a Europa-, pero también pasan de una cultura a otra: más allá de la lengua, es de la comprensión de otra cultura de lo que se trata, comprender la astronomía china no es sólo un asunto de pasar de un sistema astronómico a otro, sino de una concepción del mundo a otra, marcada por el lugar asignado a la lectura de los mensajes de la naturaleza en el gobierno de los hombres. Ricci hace gradualmente la experiencia, con la cartografía y con el cálculo del tiempo.

Así, de Cruz a Trigault, lo que revela la cuestión lingüística es el crédito que concede a quien hace la experiencia de China. Más allá de la cuestión general de la política de la lengua, que está en el corazón de toda empresa misionera como testimoniará posteriormente la creación de la congregación romana para la progagación de la fe $\mathrm{e}^{59}$, el reto de la lengua de los mandarines es doble: es, en primer lugar, el de la complejidad; es, a continuación, el de la paridad posible. Hablar, leer y escribir esta lengua se refiere a poder responder a una demanda intelectual, en vista, en último término, de hacer una propuesta espiritual.

En resumen, una trilogía que evoca las inflexiones geopolíticas de la cuestión de la evangelización y que pone a China en el centro de la atención del catolicismo cuando la competencia entre monarquías y papado, entre Lisboa, Madrid y Roma, se exacerban. Si bien no es mi intención examinar aquí la inflexión asiática de la política española al tiempo de la monarquía dual, se recordará no obstante que el interés español por Asia se concretiza en la conquista de Filipinas y el establecimiento en

57 Carta a M. de Fornari, jesuita de Padua (Macao, 13-2-1583), Ricci, op. cit. (nota 38), p. 45.

58 Carta a C. Acquaviva (Zhaoqing, 20-10-1585), ibidem, p. 103.

59 Pizzorusso, G.: "Tra cultura e missione: la Congregazione 'de Propaganda Fide' e le scuole di lingua araba nel XVII secolo", en Romano, A. (dir.): Rome et la science moderne entre Renaissance et Lumières, Roma, École française de Rome (Collection de l'École française de Rome, 403), 2008, pp. 121-152. 
Manila a partir de los años de $1560^{60}$, y en el desarrollo de intercambios comerciales entre España y Asia, con el "galeón de Manila". Por ello, China no se convierte en objeto de saber para Europa hasta este período. Por otra parte, se puede volver sobre la cuestión de una especificidad de la escritura misionera: queriendo dar cuenta de la posibilidad de progreso de los hombres de la barbarie a la fe, pone su atención en los hombres, sus cuerpos, sus costumbres; pretendiendo el reconocimiento de todo cuanto hace posible el acceso a las Luces del cristianismo, participa de un dispositivo de disciplinamiento que no sólo prioriza las categorías de saber movilizadas en esta escritura, sino que proyecta sobre China las expectativas que suscita su uso.

De este modo, vino a formar parte de Europa, convirtiéndose en su espejo, un espejo ante el que la Europa del Renacimiento de pronto se pensó.

Traducción del francés: Fernando BouzA

\footnotetext{
60 Véase el libro de Ollé, op. cit. (nota 14); SheEhan, K. J.: Iberian Asia: The strategies of Spanish and Portuguese empire building, 1540-1700, PhD thesis, Berkeley, University of California, 2008.
} 